\title{
Seroprevalence and Correlates of Hepatitis B and C Viruses among HIV Infected Children Attending an Antiretroviral Therapy Clinic in Keffi, Nigeria
}

\author{
Oti VB*, Pennap GRI and Jibril FG \\ Department of Microbiology, Nasarawa State University, Nigeria
}

Submission: September 24, 2017; Published: November 28, 2017

"Corresponding author: Oti VB, Department of Microbiology, Nasarawa State University, Nigeria, Tel: +2347069657739;

Email: Obabavictor1@gmail.com

\begin{abstract}
Hepatitis B virus (HBV), Hepatitis C virus (HCV) and Human immunodeficiency virus (HIV) are blood-borne viral infections that have been widely reported in Nigeria. The knowledge of their shared transmission routes has raised alarm about the possibility and impact of co infection with the viruses in pediatric patients. This study determined theseroprevalence and correlates of these viruses among HIV infected pediatric patients attending an antiretroviral therapy clinic in Keffi, Nigeria. Two hundred participants were screened for HBsAg and anti-HCV antibodies using rapid test kits (ACON Laboratories Inc, USA). Informed written consent was obtained from their parents/guardians and information on their socio-demographics and exposure to some possible predictors were also obtained. A general prevalence of Hepatitis B and C virus infections in the study population was $24.5 \%$. The prevalence of HBV was $11.0 \%$ while HCV was $13.5 \%$ and no child was co infected with all the 3 viruses. The viral infections were statistically associated with having scarification marks $(\mathrm{p}<0.05)$. However, gender, age, history of blood transfusion and HBV vaccination were not statistically significant possible risk factors for HBV and HCV infections ( $p>0.05)$, although there were arithmetic difference among the risk factors. The HIV/HBV and HIV/HCV co infection prevalence of $11.0 \%$ and $13.5 \%$ respectively is an emerging problem that cannot be downplayed. Routine screening of all HIV infected children for these hepatotropic viruses is necessary for appropriate to determine the correct antiretroviral treatment required according to the National guideline.
\end{abstract}

Keywords: Seroprevalence; HBV; HCV; Children; Nigeria

\section{Introduction}

The highest burden of paediatric HIV/AIDS is found in Nigeria despite a national seroprevalence of $4.6 \%$ in Sub-Saharan African $[1,2]$. Of the 2.3 million burden of HIV infected children worldwide, 90\% live in sub-Saharan Africa and Nigeria accounts for $10 \%$ of them [3]. The rate of vertical transmission is as high as $25 \%-42 \%$ in African countries [1,3]. An estimated 600,000 new paediatric infections occur each year, with over $90 \%$ of these cases occurring in sub-Saharan Africa [4]. Rapid progression of HIV-1 infection to Acquired Immune Deficiency Syndrome (AIDS) is also a major problem in these children. Up to $25 \%$ of prenatally infected infants progress to AIDS within one year and the remaining 75\% within a median period of seven years [4,5].

Both Hepatitis B and C viruses are endemic across Africa $[6,7]$. The prevalence of single infection for Hepatitis B infection in the general population in Nigeria ranges from $9 \%$ to $39 \%[6,8]$. Hepatitis $\mathrm{C}$ virus infection rate in Nigeria is also considerably high ranging from $5.8 \%$ to $12.3 \%[2,9]$. Due to the endemic nature of these viruses in the Sub Saharan region and shared routes of acquisition, co infections of HIV/HBV or HIV/HCV or even HIV/ $\mathrm{HBV} / \mathrm{HCV}$ are not uncommon. Prevalence of co infection depends on the population studied [9].

One of the major determinants of accelerated HIV disease progression is the presence of co-morbidities and opportunistic infections. The epidemiology, natural history and treatment of HIV co-infection with HBV and HCV has been studied extensively in adults but documented sparingly in children, more so among Nigerian children $[7,10,11]$. The prevalence of HBV and HCV among children on HAART (Highly active antiretroviral therapy) has been 
reported to be $14.0 \%$ in a study in Nigeria [9]. With the introduction of HAART, more people are living longer. However, this gain is being threatened by the emerging challenges posed by co-infection with HBV and HCV. And unfortunately while HBV is vaccine preventable, $\mathrm{HCV}$ is not yet. Researchers have reported the preponderance of HIV/HBV and HIV/HCV infections in Africa $[9,12,13]$.

Hepatitis B and C viral infections are known to lead to chronic infection after the acute infection especially if acquired in the perinatal period and early childhood. With improved survival due to the success of HAART, chronic viral hepatitis has become a major source of co morbidity in HIV infected populations [14]. In adults, co-infection with hepatitis $\mathrm{B}$ and $\mathrm{C}$ viruses increases the risk for hepatotoxicity of HAART and likelihood of onset of an AIDS-defining illness, compared to infection with HIV-1 alone [15]. It is unclear whether this is the same in children [15].

Most studies on HIV/HBV and HIV/HCV in Nigeria have been in adults. With increasing access to HAART in Nigeria, it is expected that more children with viral hepatitis among those with HIV will survive. This study was therefore carried out to evaluate the prevalence and correlates of HBV and HCV infections among HIV paediatric patients attending an antiretroviral therapy clinic in Keffi, Nigeria.

\section{Materials and Methods}

\section{Study area and population}

The area of study for this research was Keffi. It is approximately $68 \mathrm{Km}$ from Abuja, the Federal Capital Territory and 128Km from Lafia, the capital of Nasarawa State. Keffi is located between latitude $85^{\prime} \mathrm{N}$ of the equator and longitude $78^{\prime} \mathrm{E}$ and situated on an altitude of $850 \mathrm{M}$ above sea level [16].

A total of $200 \mathrm{HIV}$ infected pediatric patients registered for ART in a private Hospital in Keffi. Participated in this cross sectional study after an informed consent was extracted from their parents/ guardians. Their demographic information was obtained by oral interview before sample collection.

\section{Ethical clearance}

Ethical clearance and approval to conduct this study was obtained from the Health Research Ethical Committee of Nagari Hospital Keffi.

\section{Sample collection}

About $5 \mathrm{ml}$ of blood was collected from each participant by venipuncture into a clean labeled plain tube. This was allowed to clot at room temperature and spun for 5 minutes at 3000rpm. The resultant sera were harvested into well labeled cryovials and stored at -20 0C until ready for use.

\section{Laboratory investigation}

HBsAg detection: A rapid in vitro test which is a qualitative sandwich immunoassay diagnostic kit was used for screening the sera for HBsAg. The test kit (HBsAg one step test strips, ACON
Laboratories Inc, USA) utilizes a combination of monoclonal and polyclonal antibodies to detect HBsAg in serum. The test procedure and result interpretation were carried out according to the manufacturer's instructions.

Anti-HCV detection: A rapid in vitro diagnostic kit (HBsAg one step test strips, ACON Laboratories Inc, USA) was used for the detection of anti-HCV in serum. This kit uses recombinant proteins and synthesized peptides derived from core and structural regions of HCV for the detection of anti-HCV in serum. The test procedure and result interpretation were carried out according to the manufacturer's instructions.

\section{Statistical analysis}

The data obtained were subjected to descriptive statistical analysis using SPSS version 17.0. Chi-square statistical test was used to determine associations and values obtained were considered statistically significant at $\mathrm{p} \leq 0.05$.

\section{Results}

Two hundred pediatric HIV infected participants were recruited for this study. Among them were 95 (47.5\%) males and $105(52.5 \%)$ females. The overall prevalence of hepatitis in these children population was $24.5 \%$. Of these, $13.5 \%$ were reactive to anti-HCV and $11.0 \%$ to HBsAg. Females and males had higher infection rates for HCV and HBV respectively ( $p>0.05)$. When stratified by age, HBsAg and anti-HCV reactive cases were highest among children aged less than 2 years old. Infection rates with blood transfusion and HBV vaccine as possible risk factors were not statistically associated with the viral infections ( $p>0.05)$ while scarification marks was statistically associated with HBV and HCV infections $(\mathrm{p}<0.05)$.

\section{Discussion}

Infections with HBV, HCV and HIV are major public health problems because persons infected with these viruses may show no symptoms for many years and serve as reservoir for infection during these years. The need to ascertain the real burden of disease in our various localities is imperative. The seroprevalence of hepatitis carriage among participants in this study was $24.5 \%$. This is higher than findings of $14.0 \%$ in a similar study in Lafia [9], $12.9 \%$ in HIV children in Benin [17], 17.5\% among HIV adult patients in Keffi [6] and $7.5 \%$ among HIV positive children in Ethiopia [3].

HBsAg the seromarker used for HBV detection in this study was found in $11.0 \%$ of the children. This prevalence is higher than findings of 3.0\% in Lafia [9], 10.0\% in Ilorin [10], 6.2\% in Uyo [1], 7.7\% in Benin [17], 5.8\% in Owerri [18], 7.8\% in Benue [19] among HIV positive children and $6.0 \%$ among the general population in Lagos [20]. Reports among children from other countries found $10.4 \%$ in Zambia [14], 4.9\% in China [21], 1.4\% among HIV infected children and adults in Swaziland [22] and 8.8\% among HIV seropositive persons in Ghana [11]. These differences in prevalence might be as a result of the difference in study population, geographical location especially as it affects cultural practices, social indices, endemicity of 
the viruses and sensitivity of tests used for screening. The relatively high rate reported in this study is very likely to be a reflection of their low uptake of HBV vaccine in the study area. Worthy of note is also the fact that the prevalence reported in the present study did not account for occult HBV infection which will usually be possible among the HBsAg negative patients.

Similarly, the HCV/HIV co infection in this study was $13.5 \%$. This is higher than reports of $1.7 \%$ in Ilorin [10], $11.0 \%$ in Lafia [9], 2.3\% in Benue [19], 4.54\% in Lagos [23], 1.0\% in Enugu [24] among children and $1.2 \%$ among patients with kidney disease [20]. Similar studies from other countries recorded lower rates than the present study. It was 1.5\% in USA [25], 9.6\% in China [21] among children and 5.6\% among HIV infected adults in Uganda [26]. Several epidemiological studies have reported high HCV prevalence but with no apparent risk factors $[9,27]$. Differences in the seroprevalence of HCV in this study may reflect the difference in its geographical distribution, the methodologies and clinical setting of subjects as well as the different sensitivities of tests employed.

On the whole, the seroprevalence of HIV/HBV and HIV/HCV in the study population might be a reflection of the viral prevalence in their community. Thus also suggesting that the risk of predisposition to infection is the same for every member of their community. Gender was not found to be associated with the viral prevalence ( $p$ > 0.05). HBsAgseropositivity was higher in female than male while anti-HCV seropostivity was higher in male than female. This was contrary with the report of Pennap et al. [9] in Lafia, Nigeria. HBV was higher in males than females in similar studies within Nigeria $[1,10]$. However, similar studies in Lagos, Benue and Enugu reported HCV as higher in males $[19,23,24]$. The reason for the higher female predilection is not obvious. However, females are traditionally more likely to have had ear piercings at infancy as well as native aesthetic scarifications hence increasing the risk for HCV transmission especially as unsterilized sharp objects are usually used for such procedures.

The age stratification in this study did not show any statistical significance in age specific prevalence. HBsAg and anti-HCV were detected highest among children that were less than 2 years old.
This might be suggestive to some vertical transmission. This was also reported in similar studies in Nigeria $[1,9,19]$. This is in contrast to an Ethiopian study that observed infection as more common among the older children [3]. History of blood transfusion and HBV vaccination were not possible predictors for the viral infections among the study population ( $p>0.05$ ). Although, Hepatitis B and $\mathrm{C}$ viral infections were higher among those that had had a blood transfusion and $\mathrm{HBV}$ vaccination, it was not statistically significant. Other researchers have made similar observations in Nigeria $[9,18]$, Tanzania [28] and Ethiopia [3]. Prevalence of HBV infection among those that had been vaccinated might among other reasons be as a result of vaccine failure or incomplete dose uptake. In such cases the children could not have been protected. Similarly, the higher prevalence of HBV infection among those that had been transfused might partly be an outcome of the fact that the only surrogate used for blood screening for transfusion in the study area is HBsAg.

There was a statistically significant association between scarification marks and the viral infections $(p<0.05)$. The infection with HBV and HCV was higher among those with a scarification mark than those without any scarification marks. This implies that there is a likelihood of contribution to the disease burden by this unwholesome traditional practice. Similar observations have been made by Ejiofor et al. [29] in Enugu whose studies were in the Eastern part of Nigeria.

\section{Conclusion}

The present study shows a high burden of HBV (11.0\%) and HCV (13.5\%) among HIV infected children in the study area. Scarification marks was identified to be a risk factor for the infections while gender, age, history of blood transfusion and HBV vaccination were not significantly associated with the viral infections. This burden of infection is a call for alert especially as concurrent infection with these hepatotropic viruses exposes them to liver failure complications and also leads to an overlap of their pathogen city with a consequent diagnostic and treatment challenge to the Physician. This therefore necessitates the need for general awareness campaign on prevention and control and routine screening of children at risk for HBV and HCV infections (Table 1).

Table 1: Seroprevalence of Hepatitis B and C viruses among HIV infected pediatric patients attending an ART clinic in Keffi with respect to risk factors studied.

\begin{tabular}{|c|c|c|c|c|c|}
\hline \multirow{2}{*}{ Risk Factors } & \multirow{2}{*}{ No. Examined } & \multicolumn{4}{|c|}{ No. Positive } \\
\hline & & HBV (\%) & p Value & HCV (\%) & p value \\
\hline \multicolumn{6}{|l|}{ Gender } \\
\hline Male & 95 & $12(12.6)$ & \multirow{2}{*}{0.5301} & $12(12.6)$ & \multirow{2}{*}{0.7653} \\
\hline Female & 105 & $10(9.5)$ & & $15(14.3)$ & \\
\hline \multicolumn{6}{|c|}{ Age (Years) } \\
\hline$<2$ & 12 & $2(16.7)$ & \multirow{5}{*}{0.7805} & $3(25.0)$ & \multirow{5}{*}{0.6296} \\
\hline 5 -Feb & 80 & $8(10.0)$ & & 11 (13.8) & \\
\hline 9-Jun & 55 & $8(14.5)$ & & $8(14.5)$ & \\
\hline 13-Oct & 35 & $2(5.7)$ & & $2(5.7)$ & \\
\hline $14-17$ & 18 & $2(11.1)$ & & 3 (16.7) & \\
\hline
\end{tabular}




\section{Advanced Research in Gastroenterology \& Hepatology}

\begin{tabular}{|c|c|c|c|c|c|}
\hline \multicolumn{6}{|c|}{ History of Blood Transfusion } \\
\hline Yes & 54 & $10(18.5)$ & \multirow{2}{*}{0.0696} & $12(22.2)$ & \multirow{2}{*}{0.0609} \\
\hline No & 146 & $12(8.2)$ & & $15(10.3)$ & \\
\hline \multicolumn{6}{|c|}{ Scarification marks } \\
\hline Yes & 30 & $10(33.3)$ & \multirow{2}{*}{0.0003} & $9(30.0)$ & \multirow{2}{*}{0.0177} \\
\hline No & 170 & $12(7.1)$ & & $18(10.6)$ & \\
\hline \multicolumn{6}{|c|}{ History of HBV Vaccine } \\
\hline Yes & 48 & $7(14.6)$ & \multirow{2}{*}{0.42} & & \\
\hline No & 152 & $15(9.9)$ & & & \\
\hline
\end{tabular}

\section{Acknowledgement}

We are grateful to the management of Nagari Hospital, Keffi, Nigeria, parents/guardians of the recruited children for their support and assistance throughout the study.

\section{References}

1. Ikpeme EE, Etukudo OM, Etrikpo UE (2013) Seroprevalence of HBV and $\mathrm{HV}$ co-infection in children and outcome following highly active antiretroviral therapy(HAART) in Uyo, South-South Nigeria. Afr Health Sci 13(4): 955-961.

2. Okonkwo UC, Okpara H, Out A, Ameh S, Ogarekpe Y, et al. (2017) Prevalence of Hepatitis B, Hepatitis C and human immunodeficiency viruses, and evaluation of risk factors for transmission: Report of a population screening in Nigeria. S Afr Med J 107(4): 346-351.

3. Abera B,Zenebe Y,Malu W, KibretM, Kahsu G, etal. (2014) Seroprevalence of hepatitis B and C virus and risk factors in HIV infected children at the Felgehiwot referral hospital, Ethiopia. BMC Res Notes 7: 838.

4. World Health Organization (2016) HIV and hepatitis coinfection.

5. CDC Center for Disease Control and Prevention. HIV/AIDS.

6. Pennap RG, Oti BV, Alaribe AG, Ajegena SA, Galleh PR, et al. (2017) Seroprevalence of Hepatitis B and C viruses among human immunodeficiency virus infected patients accessing healthcare in Federal Medical Centre, Keffi, Nigeria. J Adv Micro 3(4): 1-6.

7. Ajegena SA, Oti BV, Pennap RG, Richard M (2017) Prevalence of HBsAg and HBV serotypes using antigen detection and PCR methods among human immunodeficiency virus patients accessing healthcare in a Tertiary Healthcare Facility in Central Nigeria. J Advan Micro 3(3): $1-10$.

8. Eze JC, Ibezako NS, Ikefuna AN, Nwokoye IC, Uleanya ND (2014) Prevalence and risk factors for hepatitis and HIV coinfection among children in Enugu, Nigeria. Afr J Infect Dis 8(1): 5-8.

9. Pennap GR, Yahuza AJ, Abdulkarim ML,Oti VB (2016) Prevalence of Hepatitis B and C viruses among human immunodeficiency virus infected children attending an antiretroviral therapy clinic in Lafia, Nigeria. The Asia J Appl Micro 3(4): 38-43.

10. Durowaye MO, Ernest SK, Ojuawa IA (2014) Prevalence of HIV coinfection with hepatitis $\mathrm{B}$ and $\mathrm{C}$ viruses among children at a tertiary hospital in Illorin, Nigeria. International J Clin Med Research 1(2): 42 47.

11. Kye-Duodu G, Nortey P, Malm K, Nyarko KM, Sackey SO, et al. (2016) Prevalence of Hepatitis B virus coinfection among HIVseropositive persons attending antiretroviral clinics in the Eastern Region of Ghana. Pan Afr Med J 25(1): 7.

12. Balogun TM, Emmanuel S, Ojerinde EF (2012) HIV, hepatitis B and C viruses coinfection among patients in a Nigerian tertiary hospital. Pan Afr Med J 12:100
13. Mathew PC, Geretti AM, Gailder PJ, Klenerman P (2014) Epidemiology and impact of HIV coinfected with hepatitis B and hepatitis $C$ viruses in sub-saharan Africa. J Clin Virol 61(1): 20-33.

14. Peebles K, Nchimba L, Chilengi R, Moore CB, Mubiana-Mbewe M, et al. (2015) Pediatric HIV-HBV coinfection in Lusaka, Zambia: Prevalence and short-term treatment outcomes. J Trop Pediatr 61(6): 464-467.

15. Onyekwere CA, Hameed I (2015) Hepatitis B and C viruses prevalence and association with demographics: Report of population screening in Nigeria. Trop Doct 45(4): 231-235.

16. Akwa VL, Binbol NL, Samaila KL, Marcus ND (2007) Geographical perspective of Nasarawa state. Onaivi printing and Publishing company.

17. Sadoh AE, Sadoh WE, Iduoriyekemman NJ (2011) HIV coinfection with hepatitis B and C viruses among Nigerian children in an antiretroviral treatment programme. S Afr J Child Health 5(1): 7-10.

18. Nwolisa E, Mbanefo F, Ezeogu J and Ahmadi P (2013) Prevalence of hepatitis B coinfection among HIV infected children attending a care and treatment center in Owerri, South Eastern Nigeria. Pan Afr Med J 14: 89.

19. Anijilaje EA, Olutola A (2013) Prevalence and clinical and immune virological profile of HIV-HBV co infection among children in an antiretroviral therapy programme in Benue state, Nigeria. ISRN Pediatrics 12 (1):1-7.

20. Amira CO, Lesi OA (2017). Seroprevalence of Hepatitis B and C infection among Nigerian subjects with chronic kidney disease. J Clinic Sci 14(2): 58-61.

21. Zhou S, Zhao Y, He Y, Li H, Balttery M, et al. (2010) Hepatitis B and C seroprevalence in children receiving antiretroviral therapy for human immunodeficiency virus-1infection in China, 2005-2009. J Acquir Immune Defic Syndr 54(2): 191-196.

22. Dzuiban EJ, Marton SA, Highey AB, Mbingo TL, Draper HR, et al. (2013) Seroprevalence of hepatitis B in a cohort of HIV infected children and adult in Swaziland. Int J STA Aids 24(7): 561-565.

23. Oyefolu AOB, Ashaka OS, Anjorin AA, Salu O, Akinyemi KO, et al. (2016) Seroprevalence of Hepatitis C virus in HIV seropositive children in Lagos, Nigeria. Afr J Microbio Res 10(2): 62-65.

24. Eze CB, Ogbodo SO, Ukoha OM, Muoneke VU, Ibekwe RC, et al. (2016) Seroprevalence and correlates of Hepatitis $C$ virus infection in Secondary school children in Enugu, Nigeria. Ann Med Health Sci Res 6(3): 156-161.

25. Schuval S, Van Dyke RB, Lindsey JC, Palumbo P, Mofenson LM, et al. (2004) Hepatitis C prevalence in children with perinatal human immunodeficiency virus infection enrolled in a long-term follow-up protocol. Arch Pediatr Adolesc Med 158(10): 1007-1013.

26. Baseke J, Musenero M, Mayanja-Kizza H (2015) Prevalence of hepatitis $\mathrm{B}$ and $\mathrm{C}$ and relationship to liver damage in HIV infected patients attending joint clinical research centre clinic, Kampala, Uganda. Afr Health Sci 15(2): 322-327. 
27. Mboto CI, Andy IE, Eni OI , Jewell AP (2010) Prevalence, sociodemographic characteristic and risk factors for hepatitis C infection among pregnant women in Calabar municipality Nigeria. Hepat Mon 10(2): 116-120.

28. Mande RH, Mmbaga BT, Damji RK, Hamel BCJ, Buchnan AM, et al. (2015) Seroprevalence and associated risk factors of HBV co-infection

This work is licensed under Creative

Commons Attribution 4.0 License

DOI: 10.19080/ARGH.2017.08.555734 among HIV infected children enrolled into a care at Kilimanjaro medical Christian medical centre Tanzania .Science Research 3(6): 324-328.

29. Ejiofor OS, Emechebe GO, Igwe WC, Ifeadike CO, Ubajaka CF, et al. (2010) Hepatitis C virus infection in Nigerians. Nigerian Med J 51(4): 173-176.

\section{Your next submission with Juniper Publishers will reach you the below assets}

- Quality Editorial service

- Swift Peer Review

- Reprints availability

- E-prints Service

- Manuscript Podcast for convenient understanding

- Global attainment for your research

- Manuscript accessibility in different formats

( Pdf, E-pub, Full Text, Audio)

- Unceasing customer service

Track the below URL for one-step submission

https://juniperpublishers.com/online-submission.php 